\title{
DISCRIMINATION OF BRAZILIAN RED VARIETAL WINES ACCORDING TO THEIR SENSORY DESCRIPTORS
}

\author{
Discriminação de vinhos tintos Brasileiros varietais \\ de acordo com suas características sensoriais
}

Alberto Miele' ${ }^{1}$ Luiz Antenor Rizzon ${ }^{2}$

\begin{abstract}
The purpose of this paper was to establish the sensory characteristics of wines made from old and newly introduced red grape varieties. To attain this objective, 16 Brazilian red varietal wines were evaluated by a sensory panel of enologists who assessed wines according to their aroma and flavor descriptors. A $90 \mathrm{~mm}$ unstructured scale was used to quantify the intensity of 26 descriptors, which were analyzed by means of the Principal Component Analysis (PCA). The PCA showed that three important components represented $74.11 \%$ of the total variation. PC 1 discriminated Tempranillo, Marselan and Ruby Cabernet wines, with Tempranillo being characterized by its equilibrium, quality, harmony, persistence and body, as well as by, fruity, spicy and oaky characters. The other two varietals were defined by vegetal, oaky and salty characteristics; PC 2 discriminated Pinot Noir, Sangiovese, Cabernet Sauvignon and Arinarnoa, where Pinot Noir was characterized by its floral flavor; PC 3 discriminated only Malbec, which had weak, floral and fruity characteristics. The other varietal wines did not show important discriminating effects.
\end{abstract}

Index terms: Sensory analysis, enology, Vitis vinifera.

\section{RESUMO}

Conduziu-se este trabalho, com o objetivo de determinar as características sensoriais de vinhos tintos brasileiros elaborados com cultivares de uva introduzidos no país há algum tempo e outros, mais recentemente. Para tanto, as características de 16 vinhos tintos varietais brasileiros foram determinadas por um painel formado por enólogos que avaliaram os vinhos de acordo com suas características de aroma e sabor. Isso foi realizado utilizando-se uma escala não estruturada de $90 \mathrm{~mm}$, a qual apresentava a intensidade de 26 descritores que foram analisados pela Análise de Componentes Principais (ACP). A ACP mostrou três importantes componentes, os quais representaram 74,11\% da variação total. De fato, o CP 1 discriminou os vinhos Tempranillo, Marselan e Ruby Cabernet, o primeiro deles sendo caracterizado pelos descritores equilíbrio, qualidade, harmonia, persistência, corpo, frutado, especiaria e carvalho, e, os outros dois, pelos descritores vegetal, carvalho e salgado; o CP 2 discriminou os vinhos Pinot Noir, Sangiovese, Cabernet Sauvignon e Arinarnoa, tendo sido o Pinot Noir caracterizado por seu sabor floral; o CP 3 discriminou o vinho Malbec, que teve descritores florais e frutados fracos. Os demais vinhos varietais não apresentaram efeito discriminatório importante.

Termos para indexação: Análise sensorial, enologia, Vitis vinifera.

\section{(Received in october 15, 2010 and approved in may 15, 2011)}

\section{INTRODUCTION}

Introduced by Italian settlers in 1875 , grape growing and winemaking are relatively recent activities in the Serra Gaúcha region, in the state of Rio Grande do Sul. Today, most of the wine produced in Brazil comes from this state, which cultivates about 35 thousand hectares of vineyards (MELLO; MACHADO, 2008). American/hybrid grapes represent the majority amongst 100 varieties from which common wine and grape juice are made. European grapes account for less than $20 \%$ of the total grape production (IBRAVIN, 2010).

Over the last years, producers have focussed on producing a variety of grapes, as in other New World countries. Nevertheless, the region still lacks an emblematic red varietal wine like Malbec in Argentina, Shiraz in Australia, Carmenère in Chile and Tannat in Uruguay.

The soil and climatic conditions in Serra Gaúcha produce medium-bodied, fruity and/or floral wines. However, wineries have a tendency to produce full-bodied wines. This means that in years when the climatic conditions are not favorable to mature grapes completely, they are macerated for many days resulting in wines with some color but low in tannin and relatively poor in fruity and floral aroma and flavor.

Twenty years ago, Brazilians mostly consumed white wine made from European varieties, but red wine has recently taken its place. This is due to many factors. One

\footnotetext{
1Empresa Brasileira de Pesquisa Agropecuária/Embrapa Uva e Vinho - 95700-000 - Bento Gonçalves - RS - Brasil - miele@cnpuv.embrapa.br ${ }^{2}$ Empresa Brasileira de Pesquisa Agropecuária/Embrapa Uva e Vinho - Bento Gonçalves - RS - Brasil
} 
factor is related to the benefits it can bring to human health (BERTELLI; DAS, 2009). Seventy years ago, red wines were produced from Barbera and Bonarda, both Italian varieties. In the 1950's, Cabernet Franc and Merlot were cultivated in addition to Italian varietals, later followed by the more famous Cabernet Sauvignon and others. But, a few years ago, Brazilian wine growers began growing a wider variety of red grapes to reduce the impact caused by the increasing amount of wine imported from abroad. Indeed, today imported wine represents at least $75 \%$ of the fine wine consumed in Brazil, of which a considerable amount is from Latin American countries, such as Chile and Argentina (UVIBRA, 2010). These wines are competitive in that they usually offer good quality and an accessible price.

Wines from these regions are frequently characterized by their intensity of color and tannin content, meaning they have considerable body, a fruity aroma and flavor. This, in addition to competitive prices, represents a strong challenge to Brazilian winemakers. To mitigate this negative impact, they are cultivating new red varieties from important wine regions of the world, such as France, Italy, Spain, Portugal and United States. It should be emphasized, however, that the characteristics of wines produced in the State of Rio Grande do Sul will probably be different than those produced with the same varieties grown in their original region (RIZZON; MIELE, 2002, 2003, 2004). The differences in physicochemical and sensory characteristics could be due to many factors, all related to the soil and climatic conditions and to the cultural and enological practices used by growers during grape growing and winemaking.

Based on this context, the purpose of this paper was to establish the sensory characteristics of wines made from old and newly introduced red grape varieties in Brazil and compare them using sensory descriptors.

\section{MATERIAL AND METHODS}

Sixteen Brazilian red varietal wines were chosen, all produced by wineries located in the state of Rio Grande do Sul, Brazil. All wine samples were from the 2007 vintage and participated in the National Wine Evaluation $\left(15^{\text {th }}\right.$ Edition), an annual event promoted by the Brazilian Enology Association (ABE). Wine samples were collected directly from the wineries, where they were stored in inoxidable tanks or oak barrels. The wines were made according to the standard technologies used by each winery.

The provenance of the sixteen grape varieties was distributed thus: France (9) - Arinarnoa (ARI), Cabernet
Sauvignon (CSA), Carmenère (CAR), Malbec (MAL), Marselan (MAR), Merlot (MER), Pinot Noir (PNO), Syrah (SYR) and Tannat (TAN); Italy (4) - Ancellotta (ANC), Barbera (BAR), Sangiovese (SAN) and Teroldego (TER); Portugal (1) - Touriga Nacional (TNA); Spain (1) Tempranillo (TEM); and United States (1) - Ruby Cabernet (RCA).

The descriptors evaluated were wine-industry standard terms, relating to aroma and flavor. The aroma descriptors were intensity (AIN), equilibrium (AEQ), quality (AQL), fruity (AFR), floral (AFL), spicy (ASP), vegetal (AVE), oaky (AOK) and off-aroma (AOA); and those related to flavor were intensity (FIN), equilibrium (FEQ), quality (FQL), fruity (FFR), floral (FFL), spicy (FSP), vegetal (FVE), oaky (FOK), sweetness (FSW), acidity (FAC), salty (FSA), bitterness (FBI), harmony (FHA), persistence (FPE), body (FBO), astringency (FAS) and offflavor (FOF).

The sensory analysis sessions were performed in May 2008 by a group of eight panelists with extensive enology backgrounds and experience in wine sensory description. The sessions were performed according to international rules (AFNOR, 1995; SSHA, 1998; MEILGAARD et al., 1999) in the Laboratory of Sensory Analysis of Embrapa Grape and Wine Research Center. Sessions started at 10 a.m. where wine samples were analyzed blind using ISO glasses, each one coded with three digit numbers and served monadically at the temperature of $17^{\circ} \mathrm{C}$. The evaluation sheet used contained an unstructured, $90 \mathrm{~mm}$-long scale of intensity for each one of the 26 variables assessed.

The resulting data was subjected to a Principal Component Analysis (PCA) (HAIR JUNIOR et al., 1995) using the Statistica 6.0 program.

\section{RESULTS AND DISCUSSION}

Figures 1 and 2 show that, on the one hand, Brazilian red varietal wines in general were characterized by their intensity, equilibrium and quality of aroma; and by their persistence, intensity, body, equilibrium, quality and harmony flavor. On the other hand, they had weak floral and oaky aromas and weak salty and floral flavor characteristics. Off-aroma and off-flavor were present in some wines, but these two descriptors were weak in most varietals.

The projection of these wines and the variables on the three principal components are shown in Figures 1 and 2. PCs 1,2 and 3 represented $42.23 \%, 23.40 \%$ and $8.48 \%$, respectively, which were responsible for $74.11 \%$ of the total variation. 

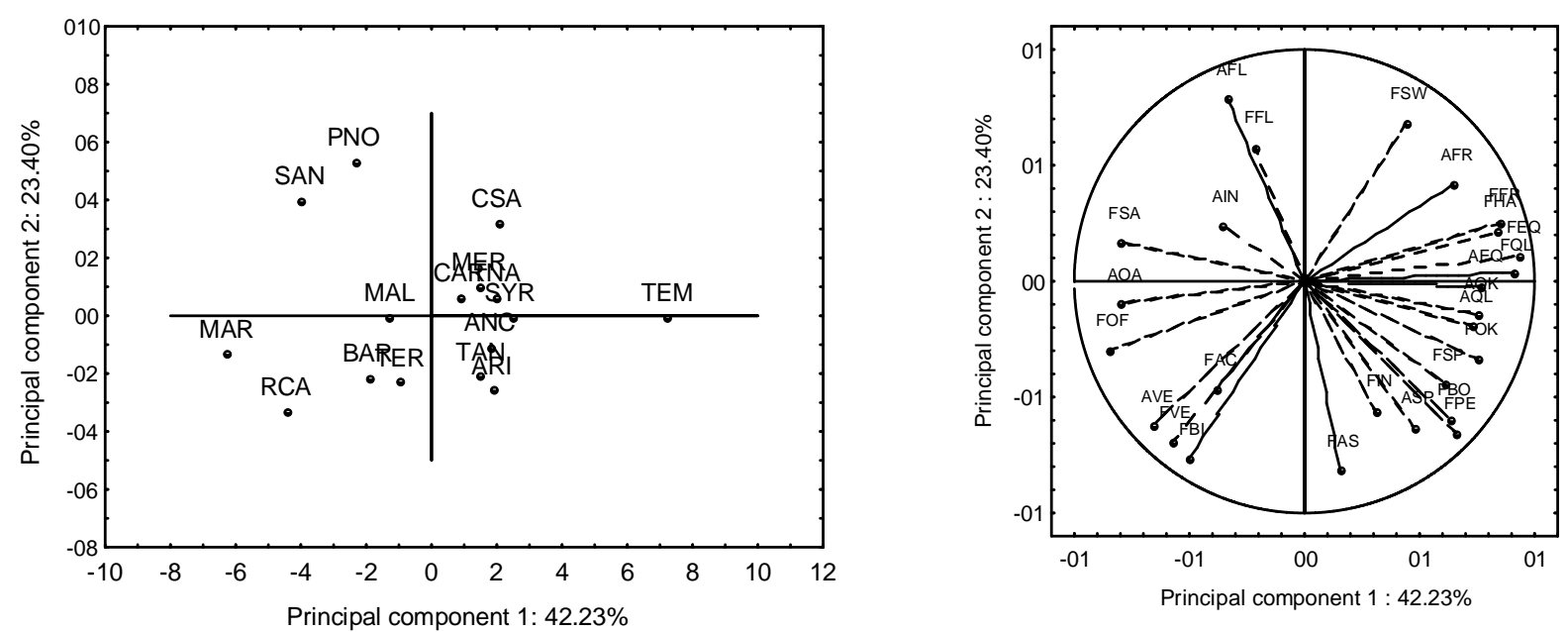

Figure 1 - Projection of the varietal wines and variables on the plane formed by the principal components $1 \times 2$. Legend: ANC - Ancellotta; ARI - Arinarnoa; BAR - Barbera; CSA - Cabernet Sauvignon; CAR - Carmenère; MAL - Malbec; MAR - Marselan; MER - Merlot; PNO - Pinot Noir; RCA - Ruby Cabernet; SAN - Sangiovese; SYR - Syrah; TAN Tannat; TEM - Tempranillo; TER - Teroldego; TNA - Touriga Nacional; A - Aroma; F - Flavor; IN - Intensity; EQ Equilibrium; QL - Quality; FR - Fruity; FL - Floral; SP - Spicy; VE - Vegetal; OK - Oaky; OA - Off-aroma; SW - sweetness; AC - Acidity; SA - Salty; BI - Bitterness; HA - Harmony; PE - Persistence; BO - Body; AS - Astringency; OF - Off-flavor.

The Principal Component Analysis (PCA) was able to discriminate eight out of the 16 wines. Indeed, PC 1 discriminated the red varietal wines Tempranillo, Marselan and Ruby Cabernet; PC 2, Pinot Noir, Sangiovese, Cabernet Sauvignon and Arinarnoa; and PC 3, Malbec. The other eight wines did not show discriminating effects.

Tempranillo wines were best characterized in PC 1 by the following variables (the correlation coefficient between each variable and the PC is indicated in parenthesis). Aroma: equilibrium (0.77), oaky (0.75), quality (0.73) and fruity (0.65). Flavor: equilibrium (0.94), quality (0.90), fruity (0.85), harmony $(0.83)$, oaky $(0.75)$, persistence (0.66), body (0.64) and spicy (0.61). On the other hand, in relation to aroma, Marselan and Ruby Cabernet wines were better characterized by the descriptors: off-aroma (-0.80) and vegetal $(-0.66)$; and in relation to flavor by off-flavor $(-0.85)$ and salty $(-0.80)$.

Tempranillo had aroma and flavor characteristics of younger wines, such as a fruity character. Besides this, it had quality and equilibrium and did not show any off-aroma and off-flavor. It is a variety cultivated mainly in the northeast of Spain but also in other countries, especially in Portugal. It was recently introduced in the state of Rio Grande do Sul, where the cultivated surface is still limited and the vineyards are young. Its sensory characteristics and agronomical behavior in this region encourage grape growers and winemakers to continue producing this varietal wine.
Marselan and Ruby Cabernet wines, on the other hand, showed the presence of vegetative aroma and flavor descriptors. Marselan was recently introduced, showing good results in some years but it was not well scored in this study. However, Ruby Cabernet was introduced many years ago when it had already presented some negative characters related to high acidity, low color intensity and weak body due to its incomplete grape ripening.

PC 2 shows that Pinot Noir and Sangiovese wines were characterized by floral (0.79) aroma and floral (0.58) flavor while Cabernet Sauvignon by its sweet (0.68) taste. Conversely, Arinarnoa wine was characterized by spicy $(-0.63)$ aroma and astringency $(-0.82)$, bitterness $(-0.76)$, vegetal (-0.69) and intense (-0.56) flavor.

Pinot Noir and Sangiovese wines had similar descriptors, mainly distinguished by their floral aroma and flavor. So far, these two varietal wines produced in the state of Rio Grande do Sul are young, low in color intensity and in tannin content. Pinot Noir was not well scored by the sensory panel as a red varietal wine, however it presents special characteristics to produce sparkling wines of good quality because it is mainly responsible for its body. Cabernet Sauvignon is a variety cultivated worldwide, and its wine is of a high quality in many viticultural regions, especially those where the climatic conditions are favorable to produce mature grapes. In the Serra Gaúcha, however, it rains considerably 
and the temperature is chilly during the grape ripening period. In general, these conditions lead to the production of vegetative wines where the green pepper character predominates due to the excessive pyrazine synthesis. Arinarnoa, a new introduced French variety, presented some negative sensory aspects related to its polyphenol composition. However, it should be taken into consideration that in France its wine has a relatively intense color.

PC 3 discriminated the varietal red wine Malbec, which was characterized by lower values of fruity (0.48), spicy (0.44) and floral (0.42) aroma and floral (0.53) flavor. Malbec is an emblematic Argentinean wine, but under the circumstances in which it is produced in the Serra Gaúcha, it did not have positive sensory characteristics. In addition, it seems that this variety has some agronomical problems when cultivated in this region. This is mainly due to the instability of grape composition during maturation and maturity over the years.

Considering the 26 descriptors evaluated, $50 \%$ of wines were not discriminated by the sensory panel. Among these wines, there are some ones with important quality characteristics. Merlot presented an intensity, quality and equilibrium of aromas; its flavor also had these three descriptors in addition to harmony, persistence and body (Figure 2). It appears to be adapted to the climate of the Serra Gaúcha region, and its characteristics may qualify it to be considered as the emblematic Brazilian red varietal wine. In general, Merlot wines have color intensity, structure and complexity. Touriga Nacional and Syrah wines also presented a nice general quality (Figure 2), but they came from another viticultural region named Campanha, where the temperature is higher and the precipitation is lower when compared to the conditions of the Serra Gaúcha. Tannat and Ancellotta wines had persistence and body (Figure 2). Besides this, they are two colored varieties that have potential to produce varietal wines or to blend with other varietals lacking in color intensity.

The behavior of Brazilian red varietal wines could be explained by several reasons. First of all, one aspect to be pointed out refers to the descriptors used, which were planned to meet the demands of the wineries. Supposedly, if other descriptors were analyzed a more important discrimination among these varietal wines could be detected. The soil characteristics, the climatic conditions and the vineyard cultural practices that predominate in the viticultural areas around the world certainly are different from those prevailing in the state of Rio Grande do Sul. However, perhaps the most important factor influencing wine discrimination is related to the technology used during winemaking. Thus, there are two main aspects to be considered. One of them is related to the kind of wine that is possible to make according to the grape characteristics produced in a specific terroir. As most of the 16 grape varieties of this study were recently introduced in this region, there is still no knowledge about an optimal
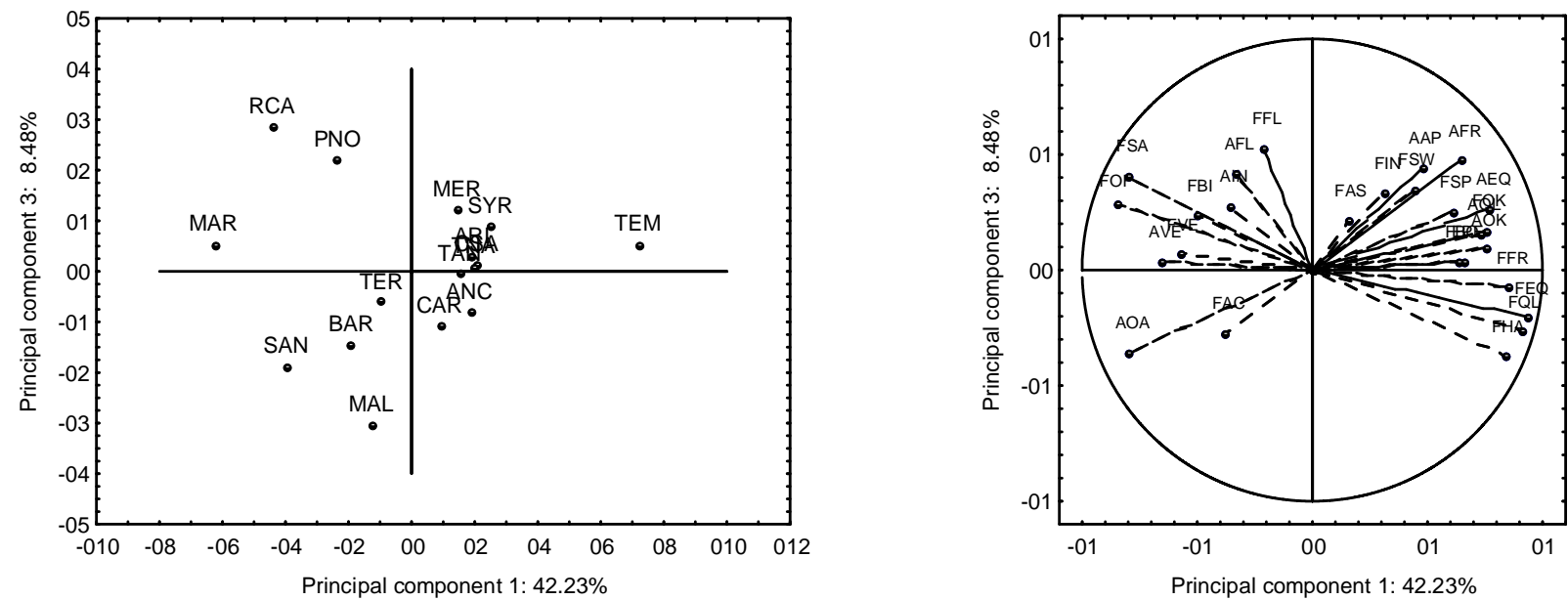

Figure 2 - Projection of the varietal wines and variables on the plane formed by the principal components $1 \times 3$. Legend: ANC - Ancellotta; ARI - Arinarnoa; BAR - Barbera; CSA - Cabernet Sauvignon; CAR - Carmenère; MAL - Malbec; MAR - Marselan; MER - Merlot; PNO - Pinot Noir; RCA - Ruby Cabernet; SAN - Sangiovese; SYR - Syrah; TAN Tannat; TEM - Tempranillo; TER - Teroldego; TNA - Touriga Nacional; A - Aroma; F - Flavor; IN - Intensity; EQ Equilibrium; QL - Quality; FR - Fruity; FL - Floral; SP - Spicy; VE - Vegetal; OK - Oaky; OA - Off-aroma; SW - sweetness; AC - Acidity; SA - Salty; BI - Bitterness; HA - Harmony; PE - Persistence; BO - Body; AS - Astringency; OF - Off-flavor. 
technology to be used to make a quality wine. The other one is related to the enological practices used during winemaking. In general, wines are made with similar winemaking technologies for most grape varieties. Therefore, the technological effect could be greater than the varietal one, thus masking the sensory perceptions of the varietal wine.

Over the last years, sensory analysis covered broad aspects related to red wine characteristics all over the world. Indeed, wine descriptors were established concerning varietal wines (GAMBARO et al., 2003; YILDIRM et al., 2005; PINHO et al., 2007); viticultural regions (SIVERTSEN et al., 1999; PAGLIARINI et al., 2004); denomination of origin (SIMON et al., 2008); wine composition (HOLT et al., 2008); vineyard cultural practices (CHAPMAN et al., 2004); enological practices (KOUSSISSI et al., 2009). In Brazil, Cabernet Sauvignon wine sensory descriptors were established according to the regions where grapes were cultivated and to wine composition (FALCÃO et al., 2007). But, as it was previously written, many factors can influence wine descriptors and typicality, being difficult to compare results obtained by different authors even if the varietal is the same.

Today, there are wines with different characteristics produced and sold in the world, some of them expressing their terroir, i.e., the prevailing effects of climatic and soil conditions. However, besides the effects of terroir, cultural practices and enological procedures may have a great influence on wine composition and sensory characteristics. Wines from European countries are still sold in considerable volumes in Brazil. This is mainly due to the importance of viticulture and enology of these countries, where Italy, France and Portugal are distinguished owing to the typicality and quality of their products and the European backgrounds of some Brazilian consumers. However, the relative importance of wine from European countries is slowly decreasing and those from the New World are increasing. Among them, wines from Chile and Argentina predominate, especially due to regional agreements and competition mainly based on quality and price. The problem is that these wines compete strongly with Brazilian ones, no matter whether the origin of the imported wines is European or South American.

Because of this international competition, actions to improve the quality of Brazilian wine are desirable and necessary. In this way, some questions should be postulated: 1) should Brazilian wines be varietal?; 2) if yes, what varietal wines are recommended considering the soil and climatic conditions of the state of Rio Grande do Sul?; 3) what should be the physicochemical and sensory characteristics of these wines?; 4) should these characteristics be determined by winemakers only or should they be established according to the consumer preference?; 5) to what markets should they be directed?; 6 ) is the price/quality relationship sufficiently competitive to avoid or, at least, to decrease the impact of imported wines? It is not easy to answer these questions in a relatively short period of time. But they are of strategic importance to the future of the Brazilian wine industry and the results of this study are offered as a preliminary set of data to be considered by enologists and wineries.

\section{CONCLUSION}

It is possible to discriminate red Brazilian varietal wines using the Principal Component Analysis. In this way, considering wines from the 2007 vintage, Tempranillo is characterized by its equilibrium, quality, harmony, persistence, body, fruity, spicy and oaky characters; Marselan and Ruby Cabernet, by their vegetal, oaky and salty characters; Pinot Noir, by its floral flavor; and Malbec, by its weak floral and fruity character. The other varietal wines do not show important discriminating effects.

\section{ACKNOWLEDGEMENTS}

Authors gratefully thank the Brazilian Association of Enology (ABE) for its support allowing us to evaluate red varietal wine samples that participated in the Wine National Evaluation - $15^{\text {th }}$ Edition.

\section{REFERENCES}

AFNOR. Contrôle de qualité des produits alimentaires. Analyse sensorielle. Paris: Afnor, 1995. 420p. (Collection Afnor Recueil de Normes Françaises).

BERTELLI, A.A.A.; DAS, D.K. Grapes, wine, resveratrol, and heart health. Journal of Cardiovascular

Pharmacology, v.55, n.6, p.468-476, 2009.

CHAPMAN, D.M.; MATTHEWS, M.A.; GUINARD, J.X. Sensory attributes of Cabernet Sauvignon wines made from vines shaving different crop yields. American Journal of Enology and Viticulture, Reedley, v.55, n.4, p.325-334, 2004.

FALCÃO, L.D. et al. A survey of seasonal temperatures and vineyard altitude influences on 2-methoxy-3isobutylpyrazine, C13-norisoprenoids, and the sensory profile of Brazilian Cabernet Sauvignon wines. Journal of Agricultural and Food Chemistry, Washington, v.55, n.9, p.3605-3612, 2007. 
GAMBARO, A. et al. Aroma characterization of commercial red wines of Uruguay. Journal of Sensory Studies, Wesport, v.18, n.5, p.353-366, 2003.

HAIR, J.F. et al. Multivariate sensory analysis: with readings. $4^{\text {th }}$ ed. Upper Saddle River: Prentice Hall, 1995. 758p.

HOLT, H.E. et al. Relationships between wine phenolic composition and wine sensory properties for Cabernet Sauvignon (Vitis vinifera L.). Australian Journal of Grape and Wine Research, Adelaide, v.14, n.3, p.162$176,2008$.

IBRAVIN. Uvas processadas pelas empresas do Rio Grande do Sul. Disponível em: < http:// www.ibravin.org.br/admin/UPLarquivos/ 220220111851472.pdf>. Acesso em: 7 dez. 2011.

KOUSSISSI, E. et al. Influence of toasting of oak chips on red wine maturation from sensory and gas chromatographic headspace analysis. Food Chemistry, Barking, v.114, n.4, p.1503-1509, 2009.

MEILGAARD, M.; CIVILLE, GV.; CARR, B.T. Sensory evaluation techniques. $3^{\text {rd }}$. ed. Boca Raton: CRC, 1999. 387p.

MELLO, L. M. R. de; MACHADO, C. A. E. (Ed.). Cadastro vitícola do Rio Grande do Sul: 2005 a 2007. Bento Gonçalves: Embrapa Uva e Vinho, 2008. 1 CDROM.

PAGLIARINI, E.; TOMASELLI, N.; BRENNA, O.V. Study on sensory and composition changes in Italian amarone valpolicella red wine during aging. Journal of Sensory Studies, Wesport, v.19, n.5, p.422-432, 2004.

PINHO, P.G. de et al. Further insights into the floral character of Touriga Nacional wines. Journal of Food Science, Chicago, v.72, n.6, p.396-401.2007.
RIZZON, L.A.; MIELE, A. Avaliação da cv. Cabernet Sauvignon para elaboração de vinho tinto. Ciência e Tecnologia de Alimentos, Campinas, v.22, n.2, p.192-198, 2002.

RIZZON, L.A.; MIELE, A. Avaliação da cv. Merlot para elaboração de vinho tinto. Ciência e Tecnologia de Alimentos, Campinas, v.23 n.Sup., p.156-161, 2003.

RIZZON, L.A.; MIELE, A. Avaliação da cv. Tannat para elaboração de vinho tinto. Ciência e Tecnologia de Alimentos, Campinas, v.23, n.2, p.223-229, 2004.

SIMON, B.F. de et al. Volatile compounds and sensorial characterization of wines from four Spanish denominations of origin, aged in Spanish rebollo (Quercus pyrenaica Willd.) oak wood barrels. Journal of Agricultural and Food Chemistry, Washington, v.56, n.19, p.9046-9055, 2008.

SIVERTSEN, H.K. et al. Classification of French red wines according to their geographical origin by the use of multivariate analyses. Journal of the Science of Food and Agriculture, London, v.79, n.1, p.107-115, 1999.

SOCIÉTÉ SCIENTIFIQUE D'HYGIÈNEALIMENTAIRE. Évaluation sensorielle: manuel méthodologique. 2.éd. Paris: Tec \& Doc, 1998. 353p. (Collection Sciences \& Techniques Agroalimentaires).

UVIBRA. Importação de vinhos e espumantes: 2004 a 2010. Disponível em: <http://www.uvibra/ dados_estatisticos.htm>. Acesso em: 7 dez. 2011.

YILDIRM, H.K. et al. Interpretation of organic wine's flavour profile by multivariate statistical analysis. Acta Alimentaria, Budapest, v.34, n.3, p.317-330, 2005. 